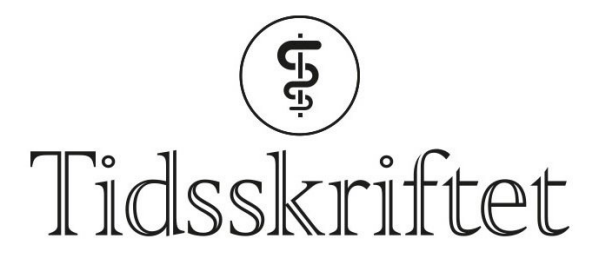

DEN NORSKE LEGEFORENING

\title{
Melanom på vei ned blant unge
}

FRA ANDRE TIDSSKRIFTER

PETTER GJERSVIK

Tidsskriftet

Forekomsten av melanom blant unge i USA er synkende, men øker blant eldre. Bedre solvaner blant unge kan være årsaken.

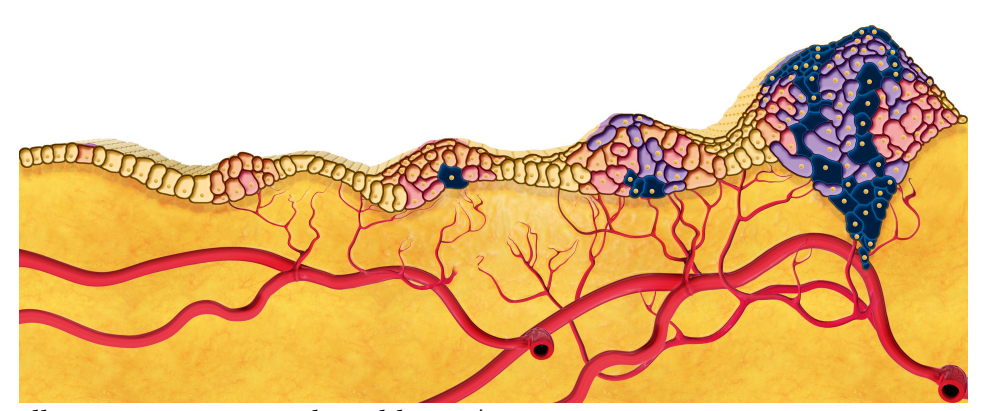

Illustrasjon: Science photo library/ NTB Scanpix

Overdreven soleksponering og solforbrenning, særlig i ung alder, er den viktigste kjente årsaken til melanom i hud. Helsemyndighetene i mange land driver derfor forebyggende arbeid der de råder folk til å begrense sin eksponering for ultrafiolette stråler fra sol og solarier. Effekten av slike tiltak begynner nå å vise seg.

I en stor populasjonsstudie i USA basert på registerdata for rundt 988 ooo tilfeller av melanom registrert i perioden 2001-15 (1), gikk insidensen av melanom ned for aldersgruppen 10-29 år, med en årlig nedgang etter 2006 på 4,4\% (95\% KI 1,7-7,0) for gutter, $5,4 \%(3,3-7,4)$ for jenter, $3,7 \%(2,5-4,8)$ for unge menn og $3,6 \%(2,8-4,5)$ for unge kvinner. Denne nedgangen står i kontrast til en økning av melanom blant voksne over 40 år, der den årlige økningen i forekomst var på 1,8 \% (1,4-2,1) hos menn og 1,8\% $\left(1,4^{-2,2}\right)$ hos kvinner.

- Dette er svært gledelige resultater, som kan tyde på at informasjonskampanjer om hudkreft og solbeskyttelse begynner å ha effekt, sier Lill Tove Nilsen. Hun er fagdirektør ved Direktoratet for strålevern og atomberedskap og leder norske helsemyndigheters strategi for hudkreft og UV-eksponering.

- Denne studien fra USA gir støtte for arbeidet med å forebygge melanom og andre former for hudkreft gjennom å oppfordre til sunne solvaner, dvs. å begrense langvarig eksponering for sterk sol, søke skygge, bruke tildekkende klær og solfaktorkrem og å la være å bruke solarium, sier hun.

- Samtidig bør vi nok legge enda mer arbeid i å fange opp melanom blant eldre, særlig blant 
menn. Norge ligger nær verdenstoppen i forekomst av melanom, og vi må prioritere arbeidet mot denne potensielt dødelige formen for hudkreft, sier Nilsen.

LITTERATUR:

1. Paulson KG, Gupta D, Kim TS et al. Age-specific incidence of melanoma in the United States. JAMA Dermatol 2019; 156: 57-64. [PubMed][CrossRef]

Publisert: 17. april 2020. Tidsskr Nor Legeforen. DOI:10.4045/tidsskr.20.0047

(C) Tidsskrift for Den norske legeforening 2020. Lastet ned fra tidsskriftet.no 